\title{
MASSIVE INTESTINAL RESECTION IN RATS FED UP ON GLUTAMINE: hepatic glycogen content valuation*
}

\author{
Ariney Costa de MIRANDA ${ }^{1}$, Paulo Engler PINTO Jr. ${ }^{2}$, \\ Sidney Resende RIBEIRO ${ }^{1}$, Samson Henrique BROMBERG ${ }^{1}$, \\ Fábio Pinatel LOPASSO ${ }^{2}$ and Kiyoshi IRYA ${ }^{2}$
}

\begin{abstract}
Background - Glutamine has been widely used in treatment of small bowel syndrome and its metabolic effects on the small intestine are well known, however, it has been little studied its effects on hepatic metabolism under this condition. Aim - To verify through experimental model, a glutamine based supplemental diet, administered via oral to rats submitted to massive intestinal resection, evaluating weight evolution and hepatic glycogen content. Material and methods - Male rats, Wistar, were allocated into three groups to undergo enterectomy. Following diets were applied: with glutamine (G group), without glutamine (NG group), and standard diet from the laboratory (R group). All animals had massive small intestine resection including ileocecal valve removal. After 20 days, all animals were sacrificed. The liver was removed to histological analysis by light microscopy. Slides were stained by periodic acid of Schiff with diastasis. Results - All animals lost weight from the beginning to the end of experiment. Comparing weight loss average expressed in percentage, there was no difference statistically significant on this variance. In analyzed groups, the hepatic glycogen content did not differ statistically, in the histological method evaluated. Conclusion - Glutamine feeding via oral did not influence weight loss reduction of animal submitted to massive intestinal resection and did not stimulate glycogen synthesis and storage into hepatocytes.

HEADINGS - Intestine, small, surgery. Glutamine. Hepatic glycogen. Rats.
\end{abstract}

\section{INTRODUCTION}

Glutamine is classified as a nonessential amino acid since it can be readily synthesized by several tissues from alpha-keto-glutarate or glutamate ${ }^{(14)}$. Skeletal muscles, lungs, adipose tissues are capable to release it into the plasma, whereas bowel and kidneys absorb it ${ }^{(18)}$. Glutamine metabolic regulation occurs in the liver, especially on catabolism state.

Liver regulation property, as well as skeletal muscles one, make them able to absorb or release glutamine according to the body need ${ }^{(8)}$. Glutamine blood levels markedly fall, more during catabolic state than others amino acids, suggesting an important role in the breakdown proteins group moved after organic damage ${ }^{(16)}$.

Probably, glutamine blood levels increase is able to put down its endogenous synthesis and/or put up its catabolism $^{(20)}$. Its exogenous resource settles or prevents the free glutamine pool typical of critical state, being able to cause weight increased, positive muscle nitrogen balance and gastrointestinal cells hyperplasia. Glutamine is a conditionally essential amino acid, not required in normal conditions, so much important in catabolic states, though ${ }^{(16)}$.

Research reports glycogen synthesis enhance in hepatocytes, emphasizing composition and stimuli mechanisms from amino acids and glutamine ${ }^{(9,11,13)}$. Hepatocyte volume enlarge stimulated by amino acids is related to hepatic glycogen formation ${ }^{(1)}$. Glutamine use in intestinal resections and its outputs on hepatic glycogen synthesis has not been studied yet.

This study aimed to check weight evolution and glycogen content in hepatocytes of rats submitted to massive intestinal resection, which were fed on isoprotein and isocaloric polymeric diet via oral, with and without glutamine.

\section{MATERIAL AND METHOD}

Twenty five male, adults, Wistar inbreed, rats were operated, with the average weight of $341,9 \mathrm{~g}$ (296 to $450 \mathrm{~g}$ ), originated from "Centro de Bioterismo"

\footnotetext{
*Paper developed in the Surgical Gastroenterology Postgraduation Program from " "Instituto de Assistência ao Servidor Público Estadual (IAMSPE)" and "Laboratório de Investigação Clínica", University of São Paulo Medical School, São Paulo, SP, Brazil.

Address for correspondence: Dr. Ariney Costa de Miranda - Av. Magalhães Barata, 979 - 505/B - 66063-240 - Belém, PA, Brazil. E-mail: ariney_costa@uol.com.br
} 
of University of São Paulo Medical School, São Paulo, SP, Brazil, in adapt period of 3 days in the laboratory.

After 12 hours in fast at night, all animals were weighed and underwent anesthesia by $50 \%$ ketamina intraperitoneal injection (11.5 mg/100 g weight), in order to perform massive intestinal resection.

\section{Surgical technique}

Following abdominal epilation, rats were fixed in polystyrene board and submitted to abdominal antisepsis using polyvinylpyrrolidone. Surgical drape was fit and medium laparotomy of $3 \mathrm{~cm}$ was performed involving skin and subcutaneous tissue, then aponeurosis and peritoneum, using rib spreader to expose full intestine. Small intestine was measured over intestine counter-mesenteriale tenue using compasses and millimetred rules, where pylorus was the starting point. Then, resection was performed, allowing $25 \mathrm{~cm}$ of proximal small intestine left as remaining part.

Following principal mesenteric vessels and its branches ligation using 4-0 cotton thread, it was performed enterectomy with cecal portion resected in $3 \mathrm{~cm}$ besides ileocecal valve. Intestinal motion recovery was performed by entero-colon laterolateral anastomosis, with 6-0 nylon continuous suture. Five $\mathrm{mL}$ of warm saline $(0.9 \% \mathrm{NaCl})$ solution was infused into peritoneal cavity, to postoperative moisturizing and abdominal muscle closure performed with a single interrupted 5-0 nylon suture.

Animals were randomly distributed into three groups, according to respective diet:

- G group: 10 rats undergone to massive intestinal resection with glutamine diet via oral.

- NG group: 10 rats undergone to massive intestinal resection without glutamine diet via oral.

- $\mathrm{R}$ group: 5 rats undergone to massive intestinal resection with standard diet from the laboratory without glutamine via oral.

- Diets: Three isocaloric and isoprotein diets were used: a) polimeric diet composed by protein hydrolyzed - (calcium caseinate - $55.5 \mathrm{~g}$ ), carbohydrate (maize amido - $162.5 \mathrm{~g}$ ) and lipid (soil oil - 16.6 g). b) polimeric diet plus glutamine composed by protein hidrolyzed (calcium caseinate $-28 \mathrm{~g}$ and glutamine $25 \mathrm{~g}$ ), carbohydrate (maize amido $162.5 \mathrm{~g}$ ) and lipidium (soil oil - $16.6 \mathrm{~g}$ ); c) standard diet from the laboratory, specific to rats and mice $\left(\mathrm{Nuvilab}^{\circledR}\right)$ which does not contain glutamine in its composition.

Animals were kept in cages with five animals in each group, separated by transparent and multidrilled partition which allowed visual and smelling contact among them. They were fed since the first postoperative day, with free water and diet and under daily clinical observation for 20 days. On the $20^{\text {th }}$ postoperative day, the animal was put under a glass cone inhaling ethylic ether until death. Quickly, wide laparotomy was performed exposing innards, taking out the liver, preserved into recipient with $10 \%$ formalin solution.

Animals were weighed at postoperative and $20^{\text {th }}$ postoperative day on electron balance, before euthanasia. Hepatic fragments were fixed in formalin during $48 \mathrm{~h}$ fixation and included to paraffin in $5 \mu \mathrm{m}$ thickness slices to histological analysis.
Slides were stained by periodic acid of Schiff (PAS) with diastasis. PAS stain evidences mucopolysaccharides presence. Mucine oxidation by PAS produces aldehyde which is strongly stained in purple by Schiff reagent. All polysaccharide and mucosubstances containing hexoses and desoxihexoses with branch glycol group stain in red by PAS (Figure 1).

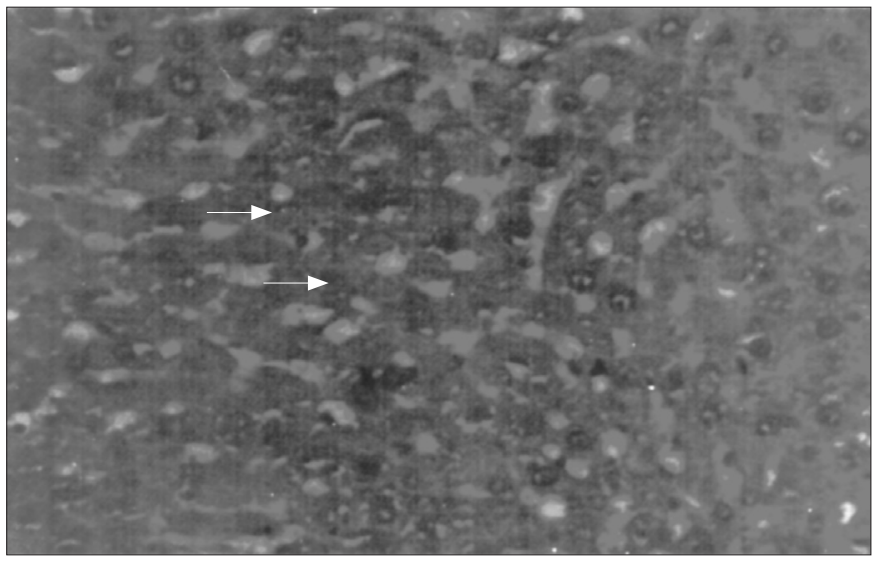

FIGURE 1 - Microphotography of one of the animal liver from G group, stained by PAS and showing cytoplasmatic granules pool in red (arrows), representing presence of polysacharide. 200 -fold increase with light microscopy

Diastasis enzyme use associated to PAS stain has the advantage because of glycogen distinction among cytoplasmatic granules in the hepatocytes throughout its digestion and reduction seen by microscopy, when compared to PAS technique without diastasis.

In order to semiquantify hepatic glycogen pool after PAS with diastasis use, a personal criteria was applied, in crosses $(+) ;(++)$ or $(+++)$.

\section{Statistical analyses}

Descriptive variances were presented in crosses $(+)$, ranging from 1 to $3(+,++$ or +++$)$, with absolute and percentage frequency calculated to each group. As statistical pattern, it was applied arithmetic average and standard deviation and analysis of variance (ANOVA) procedures, intending to evaluate rats weight loss. Fisher's exact test was employed to compare presence and semiquantification of cytoplasmatic glycogen in hepatocytes.

In all tests, it was fixed $0.05 \%$ as null hypothesis rejection level (significance level of 95\%).

\section{RESULTS}

All animals lost weight within experiment time. Weight evolution average was $43.5 \%$ in G group, $49.2 \%$ in NG group and $37.1 \%$ in $\mathrm{R}$ group. Comparison of weight loss average expressed in percentage among groups achieved no statistical significance (Table 1).

In the glycogen content study into hepatocytes, using Schiff stain with diastasis, there was no significant difference among groups $(P>0.05)$, in spite of $\mathrm{G}$ group has been presented larger pointing (++ and +++$)$, related to $\mathrm{NG}$ and $\mathrm{R}$ groups (Table 2 ). 
TABLE $1-* \mathrm{G}, * * \mathrm{NG}$ and $* * * \mathrm{R}$ groups weight loss average compared, expressed in percentage, with their respective significance level

\begin{tabular}{lcc}
\hline Groups & Weight loss average $\%$ & Significance \\
\hline G N NG & $43.5 \times 49.2$ & $\mathrm{P}>0.05$ \\
G x R & $43.5 \times 37.1$ & $\mathrm{P}>0.05$ \\
NG $\times$ R & $49.2 \times 37.1$ & $\mathrm{P}>0.05$ \\
\hline
\end{tabular}

ANOVA

${ }^{*} \mathrm{G}-$ intestinal resection + oral diet with glutamine

- intestinal resection + oral diet without glutamine

** $R$ - intestinal resection + standard diet without glutamine

TABLE 2 - Comparison of glycogen accumulation into hepatocytes among $* \mathrm{G}, * * \mathrm{NG}$ and $* * * \mathrm{R}$ and $\mathrm{NG}$ groups, expressed in percentage, semiquantified in,+++ and +++ , studied by PAS differing on diastasis

\begin{tabular}{lcccccccc}
\hline GROUPS & & + & & ++ & \multicolumn{2}{c}{+++} & TOTAL \\
\hline \multirow{2}{*}{ G } & $\mathrm{N}$ & $\%$ & $\mathrm{n}$ & $\%$ & $\mathrm{n}$ & $\%$ & $\mathrm{~N}$ \\
NG & 2 & 20 & 4 & 40 & 4 & 40 & 10 \\
R & 4 & 40 & 3 & 30 & 3 & 30 & 10 \\
TOTAL & 3 & 60 & 1 & 20 & 1 & 20 & 5 \\
\hline
\end{tabular}

Fisher's exact test $P>0.05$

${ }^{*} G$ - intestinal resection + oral diet with glutamine

**NG - intestinal resection + oral diet without glutamine

$* \star * R-$ intestinal resection + standard diet without glutamine

\section{DISCUSSION}

Metabolic and nutritional changes following enterectomies depend on the resected segment (ileum and jejunum) and on presence of ileocecal valve ${ }^{(15)}$. It was noticed on pilot study of this work, where high death levels were present in groups undergone to intestinal extended resection associated to ileocecal valve removal.

Resection of $95 \%$ of small intestine in rats, preserving ileocecal valve was associated to significant weight loss in first 10 days, achieving stabilization, though ${ }^{(19)}$.

The postoperative observation time used in this study, to collect was 20 days, maximum period achieved with $75 \%$ resection of distal small intestine and ileocecal valve resection. Once ileocecal valve is an important factor on diarrhea control and consequent morbidity-mortality ${ }^{(4)}$.

Via oral as a way to administrate nutrients in experimental works, has been little used, mainly when catabolic state is tested, and when compared to via parenteral, perhaps because in the majority of clinical cases, this via is not available or what if, would not be so effective. On the other hand, via parenteral is widely used in malnourishment treatment, what lead to propose experimental models of parenteral nutrition in rats, although this via is not free of complications, because when used for a long time, it was associated to hepatic lipid accumulation, mainly triglycerides and cholesterol. As for its exclusive use in nutritional replacement, it was concluded very frequently and early, the hepatic steatosis onset ${ }^{(5,21,22)}$.

Under catabolic state, systemic and intracellular amino acids levels fall, where glutamine plays the role of important factor that affects protein synthesis ${ }^{(17)}$.

Glutamine administration via oral may increase plasma levels until $46 \%$, suggesting that a significant glutamine portion escapes from intestinal use, to be absorbed and metabolized by liver and kidney, returning to blood circulation. It may suggest via oral efficiency under this amino acid administration ${ }^{(3)}$.

In the current study, use of via oral to administrate nutrients containing glutamine did not allow notice specific alterations into the hepatic glycogen content, under absorption deficit. Diet consumption by rats was enough and similar among the three groups. It leads to understand that this choice has not influenced on diet consumption by the rats, enhanced by nutrients well utilization in animal models when related to this via, once there is no absolute contra-indication to its use.

In our research, all rats lost weight ranging widely from initial and final weight, after have being submitted to intestinal resection, reaching until $49.2 \%$ as weight loss average (NG group), with no chance to stabilization thanks to nutritional unbalance after continuous diarrhea.

Larger averages of weight loss appeared in $\mathrm{G}$ and $\mathrm{NG}$ groups. However, when three groups were compared, there were no statistically significant values. It leads us to confirm that glutamine addition did not carry to weight loss reduction in animals submitted to resection. Standard diet (R group) from the laboratory was more efficient, though, presenting smaller weight loss. That is not easy to explain these findings, once all diets were isocaloric and isoprotein. One probably explanation is based on the concept that glutamine added to isocaloric and isoprotein diet, required $50 \%$ reduction in other amino acids fractions, leading to protein synthesis damage. On the other hand, simply glutamine addition would implicate turn the hyperprotein diet into not comparable diets.

Histological analysis of cytoplasmatic granules in hepatocytes by PAS technique with diastasis showed that glycogen quantification did not differ statistically among the three groups. It may suppose that animals, after massive intestinal resection, used the majority of exogenous glutamine in the intestine, intending to improve its absorptive capacity, with less glycogen absorption and synthesis into hepotocyte, consequently.

Regulation of systemic levels of glucose occurs in the live through amino acids absorption following glycogen synthesis and storage (glyconeogenesis). Glycogen break down leads to glucose release, mainly in the period between the meals and in the beginning of extent fast, until its finish ${ }^{(2)}$. Glutamine plays a role as carbon resource to glyconeogenesis and ammonia for the urea cycle $^{(7)}$.

Glutamine is a gliconeogenesis primor which is able to enhance the glucose homeostatic keeping in periods of high requesting and its glycogen tissue reserves are low ${ }^{(6)}$.

Glutamine hidrolisis occurs in the hepatocytes, by glutaminase action in order to provide substrates (ammonia and glutamate), used in the urea cycle and glyconeogenesis respectively. On opposite reaction, these substrates catalized by glutamino sintetase compose glutamine ${ }^{(12)}$.

In clinical catabolic states, it is known glucose and amino acids pick up increasing from blood circulation to the liver, as well as its storage on glycogen form. In isolated hepatocytes of rats, this aspect was studied from several substrates, with glucose in high concentration as the greatest responsible by this accumulation ${ }^{(21)}$. Significant increasing on the glucose absorption occurs when amino acids, as glutamine, are added, emphasizing the marked 
role in the glycogen synthesis regulation ${ }^{(10)}$. On rats undergone to fast for different periods of time, glutamine is the best substrate to hepatic glycogen compose after the third day, through the cellular volume enlarge and the glucogen sinthetase enzyme which in its active form is responsible for the synthesis ${ }^{(13)}$.

Glucose formation mechanisms stimulated by amino acids in the liver are not completely known. Reports refer several hypotheses that should be more explained. In spite of experimental researches emphasize metabolism aspects without mention clinical situations which involve massive intestinal resection and its outcomes on organs as the liver.
In the present study, it was focused the glycogen content in the liver stimulated by glutamine via oral, evaluated by histological analysis.

\section{CONCLUSION}

It was concluded that glutamine did not contribute to reduce weight loss in animals submitted to intestinal resection. Glutamine feeding via oral was noticed as not providing glycogen accumulation in significant amount, in the hepatocytes, in rats submitted to massive intestinal resection.

Miranda AC, Pinto Jr PE, Ribeiro SR, Bromberg SH, Lopasso FP, Irya K. Ressecção intestinal extensa em ratos tratados com oferta oral de glutamina: avaliação do conteúdo hepático de glicogênio. Arq Gastroenterol. 2006;43(1):55-8.

RESUMO - Racional - A glutamina tem sido utilizada amplamente no tratamento da síndrome do intestino curto e seus efeitos metabólicos são bem conhecidos no intestino delgado, porém pouco se tem relatado sobre seus efeitos no metabolismo hepático nessa condição. Objetivo - Verificar em modelo experimental, o efeito de dieta suplementada com glutamina administrada por via oral, em ratos submetidos a ressecção intestinal extensa, na evolução ponderal e no conteúdo de glicogênio hepático. Material e métodos - Ratos Wistar machos foram distribuídos em três grupos enterectomizados. As seguintes dietas foram utilizadas: com glutamina (grupo G), sem glutamina (grupo $\mathrm{NG}$ ) e a dieta padrão do laboratório (grupo R). Em todos os animais a ressecção extensa do intestino delgado incluiu a válvula íleo-cecal. Após 20 dias os animais foram sacrificados. O fígado foi retirado para estudo histológico por microscopia ótica. As lâminas foram coradas pelo ácido periódico com base de Schiff com diastase. Resultados - Todos os animais perderam peso entre o inicio e o final da pesquisa. Na comparação da perda média de peso expressa em percentagem, não houve diferença estatística em relação a essa variável. Nos grupos estudados o conteúdo de glicogênio no hepatócito, avaliado por método histológico, não diferiu estatisticamente. Conclusões - A oferta de glutamina por via oral não contribuiu para redução da perda de peso dos animais submetidos a ressecção intestinal extensa e não estimulou a síntese e armazenamento de glicogênio nos hepatócitos.

DESCRITORES - Intestino delgado, cirurgia. Glutamina. Glicogênio hepático. Ratos.

\section{REFERENCES}

1. Baquet A, Hue L, Meijer AJ, Van Woerkom GM, Plomp PJAM. Swelling of rat hepatocytes stimulates glycogen synthesis. J Biol Chem. 1990;265:955-9.

2. Bode BP, Souba WW. Glutamine transport and human hepatocellular transformation. JPEN J Parenter Enteral Nutr. 1999;23(5 Suppl):S33-7.

3. Bowtell JL, Gelly K, Jackman ML, Patel A, Simeoni M, Rennie MJ. Effect of ora glutamine on whole body carbohydrate storage during recovery from exhaustive exercise. J Appl Physiol. 1999;86:1770-7.

4. Gazet JC, Kopp. Surgical significance of ileocecal junction (1964) apud Weser E. Nutritional aspects of malabsorption. Am J Med. 1979;67:1014-20.

5. Gonçalves EL, Yamaguchi N, Waitzberg DL, Mello-Filho GB. Nutrição parentera em ratos: aspectos técnicos. Acta Cir Bras. 1990;5:17-22.

6. Halseth AE, Rheaume N, Messina AB, Reed EK, Krishna MG, Flakoll PJ, Lacy DB, Wasserman DH. Regulation of hepatic glutamine metabolism during execise in the dog. Am J Physiol. 1998;275:655-64.

7. Haussinger D. Nitrogen metabolism in the liver: structural and functional organization and physiological relevance. Biochem J. 1990;267:281-90.

8. Inoue Y, Bode BP, Souba WW. Dietary regulation of the hepatic system $\mathrm{n}$ glutamine transporter in tumor-bearing rats. Am J Surg. 1995;169:173-8.

9. Katz J, Golden S, Wals PA. Stimulation of hepatic glycogen synthesis by amino acids. Proc Natl Acad Sci USA. 1976;73:3433-7.

10. Katz J, Golden S, Wals PA. Glycogen synthesis by rat hepatocytes. Biochem J. 1979;180:389-402.

11. Lavoinne A, Husson A, Quillard M. Glutamine et cellule hépatique: métabolisme, propriétés et concept de régulation du métabolisme par le gonflement cellulaire. Ann Biol Clin. 1998;56:557-62.

12. Meijer AJ, Baquet A, Gustafson L, Van Woerkom GM, Hue L. Mechanism of activation of liver glycogen synthase by swelling. J Biol Chem. 1992;267:5823-8.
13. Mouterde O, Claeyssens S, Chedeville A, Lavoinne A. Glutamine is a good substrate for glycogen synthesis in isolated hepatocytes from $72 \mathrm{~h}$ - starved rats, but not from $24 \mathrm{~h}$ - or 48h - starved rats. Biochem J. 1992;288:795-9.

14. Neu J, Shennoy V, Chakrabarti R. Glutamine nutrition and metabolism: where do we go from here? Faseb J. 1996;10:829-37.

15. Schulzke JD, Schmitz H, Fromm M, Bentzel CJ, Riecken EO. Clinical models of intestinal adaptation. Ann N Y Acad Sci. 1998;859:127-38.

16. Smith RJ, Wilmore DW. Glutamine nutrition and requirements. JPEN J Parenter Enteral Nutr. 1990;14(4 Suppl):94s-9.

17. Souba WW, Austgen TR. Interorgan glutamine flow following surgery and infection. JPEN J Parenter Enteral Nutr. 1990;14(4 Suppl):90s-3.

18. Stumvoll M, Perriello G, Meyer C, Gerich J. Role of glutamine in human carbohydrate metabolism in kidney and other tissues. Kidney Int. 1999;55:778-92.

19. Waitzberg DL, Cukier C, Mucerino DR, Logulo AF, Torrinhas RSM, Castro I. Small bowel adaptation with growth hormone and glutamine after massive resection of rat's small bowel. Nutr Hosp. 1999;14:81-90.

20. Watford M, Darci-Vrillon B, Duée PH. Dietary glutamine suppresses endogenous glutamine turnover in the rat. Metabolism. 2000;49:141-5.

21. Yeh SL, Chen WJ, Huang PC. Effect of L-glutamine on hepatic lipids at differen energy levels in rats receiving total parenteral nutrition. JPEN J Parenter Enteral Nutr. 1994;18:40-4.

22. Zamir O, Nussbaum MS, Bhadra S, Subbiah MTR, Rafferty JF, Fischer JE. Effect of enteral feeding on hepatic steatosis induced by total parenteral nutrition. JPEN J Parenter Enteral Nutr.1994;18:20-5. 